\title{
Baltic impetus on the Baltic Finnic diphthongs
}

It is universally agreed in traditional Finno-Ugric comparative linguistics that the Uralic (and Finno-Ugric) protolanguage had no diphthongs. However, this statement seems too categorical, if we take into account that Finno-Ugric reconstructions contain the syllabic combinations $V+j$ and $V+$ $v$ which are phonetically equivalent to $V+i$ and $V+u$ : Uralic *äjmä, *päjwä, *våjni, *ojwå, etc. (J. Janhunen 1981). In any case these combinations are quite marginal as to their frequency and do not alter the general picture of FU (Uralic) monophthong vocalism. Outside of Baltic Finnic and Lapp this original phonetic/phonotactic state has been retained quite well, with some sporadic diphthongization due to phonetic context in the Eastern branches and in Old Hungarian notwithstanding. In fact, diphthongs ending in non-syllabic $i$ and $\ddot{u}$ occur, with limited frequency, in Votyak, Zyryene, Vogul, Ostyak, and Samoyed. These changes have remained marginal and without any importance for the vowel systems as a whole (B. Collinder 1957, G. Décsy 1965, E. Itkonen 1962, W. Steinitz 1964). In this respect - monophthong vocalism - the Finno-Ugric languages show typological affinity with the Altaic ones.

The reconstructed vocalism of the Indo-European protolanguage represents the opposite type. It is supposed to have had the following (at least

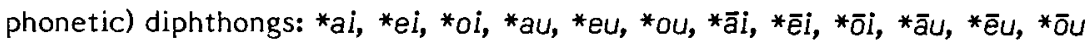
structurally often rendered as $V+j$ or $v$, to use the same notation as for Uralic above (O. Szemerényi 1970). In various stages of their history the modern Indo-European languages show different degrees of conservation of diphthongs, although monophthongization or fusion of original diphthongs is not rare (PIE *aug- > Skt ojas, Latin augeo, Gothic aukan, Swedish öka, Lithuanian áugu; PIE *loukos > Latin lücus, Lith. laũkas), and late diphthongization is notable both in Germanic and Romance (Old English tima > 
NE time [taim]; Latin rota > Italian ruota). This both-ways variety is particularly characteristic of the Western Indo-European group, whereas the East has tended predominantly to monophthongize. In Proto-Slavic all diphthongs are monophthongized (PIE *tauros > OCS turŭ, PIE *bheudh-> OCS buditi), and Sanskrit shows analogous development: all short diphthongs are monophthongized and the six long ones have been reduced to two (PIE *deiwos > Skt devah, PIE *nāus > Skt nauh, PIE *g ${ }^{w} \overline{o u s}>$ Skt gauh). It might be possible that the typological model of Uralic or Altaic vocalism has influenced the monophthongization tendency in earliest Slavic. This is by no means unexpected, since Finno-Ugric - and in a wider sense Uralic and Altaic - substratum phenomena, especially in syntax, seem to be significant in Slavic (primarily Russian; V. Kiparsky 1969, W. Veenker 1967).

The Baltic languages, whose phonetics is generally considered conservative, have preserved the original diphthongs better than the other modern Indo-European languages. Only their number has been reduced through qualitative and quantitative fusion. The difference between Baltic and Slavic is striking in this respect (e.g. Lith. véidas > OCS vidü), since the two groups show otherwise conspicuous phonetic, prosodic, morphological, syntactic and lexical affinity.

According to C. Stang 1966 Proto-Baltic had the following diphthongs:

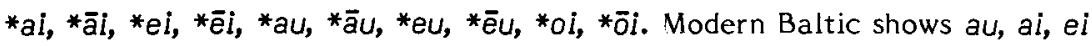
and the innovative diphtongs ie, vo, and ui (A. Senn 1966, J. Endzelins 1971). The phonemic status of the Baltic diphthongs (primarily Lithuanian) has provoked much discussion. Among Baltists there are divergent opinions about the question whether the Baltic diphthongs are separate, autonomous unit phonemes or biphonemic vowel combinations (A. Klimas 1970). This debate has no essential importance in this survey, the aim of which is to consider the Baltic influence on the Western Finnic diphthong innovation. The Baltic Finnic diphthongs have a clear biphonemic character, and are considered here simply as sequences of two vowels.

It is worth discussing why the number of diphthongs in Western Finnic (especially in Finnish) is greater than in any other European language (L. Hakulinen 1979), in contrast to the rest of the Finno-Ugric family, which on the whole has maintained the original state of monophthongal vocalism. In fact, diphthongs are essential elements of the vowel system only in Baltic 
Finnic and Lapp. However, no proper diphthongization process can be shown, expect for the late Finnish-Karelian change $\bar{e}>i e, \bar{o}>$ vo, $\bar{o}>$ yö. We can only note that the rich series of falling diphthongs of Proto-Finnic origin ai, äi, oi, öi, vi, üi, ei; au, äü, ou, öü (late), eu, eü, iu, iü (L. Posti 1942) became, at some point, essential phonotactic elements of the Western Finnic lexical corpus. It is surely not mere chance that the situation is like this in the only Finno-Ugric branch that for 3000 years - according to some opinions still longer - has been in close contact with Indo-European languages. Nobody doubts that there has been a prolonged and intensive cultural and linguistic symbiosis between the Baltic Finnic tribes and the Balts. This state of affairs is clearly reflected in the numerous Baltic loan words. This symbiosis may be compared with that between Bolgar-Turks and old Hungarians. It has also been proved that the material culture, even the racial characteristics of the Western Finns, were decisively modified during the Baltic contacts. Evidence of the solidity of these contacts is given especially by such Baltic loan words in Baltic Finnic as Finnish tytär, Estonian tütar (cf. Lith. duktẽ) 'daughter', Fi. morsian, Est. mörs (cf. Lith. martì) 'bride', Fi. reisi, Est. reiz (cf. Lith. rietas) 'thigh', Fi. hammas, Est. hammas, Livonian āmbaz (cf. Lith. Zambas, Latvian zùobs) 'tooth'. The names for the family members and parts of the body normally belong to the oldest native lexical corpus and are not easily borrowed. Familiar intercourse beyond language boundaries in the archaic agrarian community is verified by many Baltic loan words in Baltic Finnic which belong to agricultural, dairy, and household terminology, such as Finnish heinä, EstN hein, EstS hain (cf. Lith. Siênas) 'hay', Fi. vuohi (cf. Lith. ožys) 'goat', Fi. reki, Est. regi (cf. Lith. rãgès) 'sleigh', Fi. kauha (cf. Lith. káư̌as) 'dipper'.

The number of old Finnic loan words in Baltic is minimal. The most reliable examples of this opposite direction of borrowing seem to be Lith. kadagys, Latv. kadegs, Old Prussian kadegis (cf. Fi. kataja) 'juniper' and Latv. cimds (cf. Fi. kinnas <*kimdas) 'mitten' (J. Kalima 1936). W. Thomsen 1890 tried to explain this disproportionate relation of influence by assuming that the Baltic tribe which was closely affiliated with the Western Finns became extinct before the historical era. J. Kalima also adopts this explanation. However, it would be more natural to think that the demographic superiority and the higher cultural level of the Balts determined this uni- 
lateral tendency of borrowing. An analogous question of prestige comes out in the relationship between Finnish and Lapp: there are many more Finnish loan words in Lapp than vice versa. Furthermore, many Baltic Finnic loan words have been adopted later by the Baltic and the other neighbouring Indo-European languages, especially from Estonian and Livonian into Latvian and from Finnish dialects into Russian and Swedish. This could happen and did happen - after the leveling of prominent cultural differences in the Baltic area.

Thorough and substantial research has been carried out in the field of loan words, but phonetic, morphological and syntactic borrowing in the Baltic contact area has only been the target of sporadic investigation. According to the traditional and often strictly dogmatic conception only words are subject to borrowing, while other elements of language develop and change on the basis of their own inherent conditions. In the field of syntax attention has been paid to such evident Indo-Europeanisms in Baltic Finnic as nominal congruence and the complex tense systems, unknown in the original Finno-Ugric syntax. U. Korhonen $1981^{1}$, briefly lists the Western Finnic syntactic innovations which deserve exhaustive investigation, whereas the possibility of Finno-Ugric influence on Indo-European (primarily Russian) has been examined in more detail (Kiparsky, Veenker).

L. Posti 1953 gave a new explanation to the numerous Proto-Baltic Finnic consonant changes, deducing that most of them were caused by foreign, Baltic or Germanic, influence and were the results of substitution processes in bilingual contexts. According to Posti even such a central phenomenon as Baltic Finnic consonant gradation is due to foreign (Germanic) influence. Posti's theory provoked somewhat contradictory reactions (see Virittäjä 1953). His accurate and well-founded arguments were appreciated, but the assumption of such an extensive foreign influence on Proto-Baltic Finnic aroused scepticism compatible with the then prevailing research mentality, still bound to the Neogrammarian tradition.

Posti's methodological principle has been lately reutilized on several occasions. One of the most recent of such contributions is A. Plöger's 1982 discussion of Proto-Baltic Finnic word structure $C \bar{V} C(C) a / a ̈$. She considers it possible that the formation of words of this type was determined to a large extent by foreign (Baltic and Germanic) influence. 
It is also fully legitimate to apply Posti's method to the history of Baltic Finnic vocalism. The strong increase of words with diphthongs during and after the Proto-Baltic Finnic age was such a radical typological innovation that it is worth while searching for a causal connection in language contacts.

The first syllable is of primary interest, when one tries to explain the formation of diphthongs as tautosyllabic vowel sequences. In any modern text diphthongs are more numerous in the second and the third syllable, but there they generally derive from the combination of a thematic vowel and a derivational or infectional suffix (M. Rapola 1966: 392), and they are not as equally "independent" as the diphthongs of a radical, non-derived syllable. A clear example of this relationship is the distribution of the diphthong oi in Finnish: $O i$ is statistically the most frequent one in any text, because stems in $a+i$ (plural, past tense) $>$ oi (K. Häkkinen 1982). In contrast oi in the first syllable is rather rare.

The detailed examination of these phonotactic units (Baltic Finnic diphthongs) is based on the perusal of the etymological dictionary of the Finnish language, SKES, which is obviously not a complete corpus, but the most adequate tool for historical investigations. SKES contains about $600^{1}$ words which have a Proto-Baltic Finnic diphthong in the first syllable. Less than 50 of these words are older than Proto-Baltic Finnic, having equivalents in Eastern Finno-Ugric languages. For some of them, however, a Finno-Ugric etymology is uncertain with regard to the diphthong, e.g. for Fi. kainalo, lauha and kuivaa. During the Proto-Baltic Finnic period falling diphthongs were formed through the vocalization of $j$ and $v$ into $i$ and $u$ in contracted monosyllabic words when the initial $j$ and $v$ of the second syllable became syllable-final, and in bisyllabic words at the end of the first syllable before a consonant: Fi. voi, Est. voi <*voj<voje, Fi. täi <*täj<*täje, Fi. (savi) sau<*sav < *save, kaiva- <*kajva-, touko <*tovko. Diphtongs came about

\footnotetext{
1 Exact counts are not given, because some words of extremely marginal distribution like Lapp loan words in Northern Finnish dialects and clearly derivational formations have not been considered. Besides, the absolute number of words with diphthongs is increased because of the diphthongs ie $(<\bar{e})$, vo $(<\overline{0})$ and yö $(<\bar{O})$ which arose during the separate evolution of the Finnish (and Karelian) language and are not treated in this article.
} 
also through the vocalization of ${ }^{*} n$ : Fi. jauhaa, Est. jahvada < Pre-Baltic Finnic janక̌a- (cf. Mordvin jažams), Fi. seisoa, Est. seisma salzma <

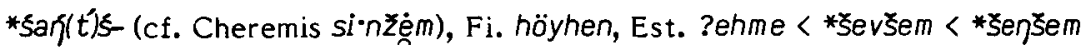
(E. Itkonen 1949: 27-28; 1959: 306-311; 1969: 89, 101-102).

It does not seem likely that indigenous combinative changes have given rise to the rich Baltic Finnic corpus of words with diphthongs in such a restricted number of old words. Furthermore, in some cases the diphthong of the first syllable is not "motivated", e.g. Fi. kainalo, saivar and peukalo, in which the second component of the diphthong cannot derive from the Proto-Baltic Finnic consonants $v, j, \eta$, the candidates prone to vocalize. In these words the diphthong has been formed ex novo of whatever antecedents.

The process of diphthongization was probably carried out after the common Baltic Finnic - Lapp period and before late Proto-Baltic Finnic times (E. Itkonen 1949: 28). In fact, the Lapp diphthong system shows a separate development with respect to the Baltic Finnic one (L UF). In the period from Pre-Baltic Finnic to Late Proto-Baltic Finnic the Baltic Finnic tribes came in close contact with the Indo-European Balts and Germanic groups, and in this era radical phonetic changes took place, especially in consonantism. Because examples of diphthongization in native FU words are few and also because all the words with diphthongs cannot be explained through phonetic changes, it is reasonable to assume the same kind of foreign influence that L. Posti 1953 has seen in the Proto-Baltic Finnic consonant changes.

I. $a i, e i, a u, e u$

Of the 600 Finnish words with diphthongs 300, i.e. one half, are loan words, if we consider also the late Swedish and Russian borrowings. More than 200 , i.e. two thirds of the total number of loans having a diphthong in the first syllable, contain $a i$, ei, au or eu. Furthermore, the words in this group generally belong to the oldest, Baltic or Germanic, stratum. These diphthongs existed in the first syllable in Proto-Baltic and they are reflected in a series of Baltic loan words in Proto-Baltic Finnic: Fi. kaikki, Est. köik (cf. Lith. kiek, kiekvienas), Fi. kaima, Est. kaim (cf. Lith. káimas, kiēmas), Fi. laiha, Est. lahi (cf. Lith. liesas), Fi. laiska, Est. laisk (cf. Latv. 
laîsks), Fi. paimen, Est. paimendama (cf. Lith. piemuo, acc. sg. piemeni), Fi. taivas, Est. taevas (cf. Lith. diẽvas), Fi. heimo, Est. höim, Liv. aìm (cf. Lith. Šeimà), Fi. heinä, EstN hein, EstS hain (cf. Lith. Šiēnas), Fi. reisi, EstN reiź, EstS raiz (cf. Lith. rietas), Fi. seinä, EstN sein, EstS sain (cf. Lith. siena), Fi. kauha, Votic kavi < *kauhi (cf. Lith. káư̌as), Fi. laukki, Est. lauk (cf. Lith. laũkis), Fi. leuka, Est. loug (cf. Lith. liaukà), Fi. reuna, Veps reün (cf. Lith. briauna). Only some of these loans have an equivalent in Lapp, which corresponds to the general numerical ratio between Baltic loan words in Baltic Finnic and Lapp (100:20). It is significant, however, that also Lapp reflects Proto-Baltic Finnic diphthong forms: Lapp suoidne Fi. heinä, Lapp guoibme Fi. kaima, Lapp kau ${ }^{a} \mathrm{Ca}_{a} \sim \mathrm{Fi}$. kauha.

Language contacts brought Proto-Baltic Finnic and Proto-Baltic phonetics and phonotactics into confrontation with each other, and it is to be expected that bilingual speakers would diffuse the diphthongs of the first syllable into Baltic Finnic lexical corpus substituting e.g. the first sections of the combinations $V \eta-\xi v, V \eta-r V, V \eta j-t \xi v$, which seem to be unknown in Baltic (cf. A. Kurschat 1973; see also L. Posti 1953: 31), with diphthongs like ai, ei, au, eu, e.g. in Fi. jauhaa < *janక-, aurinko < *anre- (shaky because no cognates exist), seisoa, Est. salzma <*sag(t')s, höyhen (heühen)<

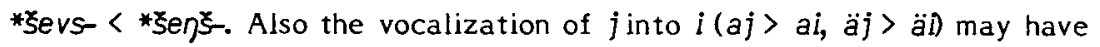
been favoured by Baltic speech habits.

It is not necessary to assume that Baltic influence was the only and primary factor in the outcome of diphthongs, especially for the Baltic Finnic words of FU origin, but in all probability the Baltic and Baltic Finnic phonetic interaction has decisively strengthened the category of diphthongs in Baltic Finnic. L. Posti 1953 has seen the conspicuous influence of Baltic and Germanic speech habits in the loss and change of isolated Proto-Baltic Finnic consonants and consonant clusters. Increasing attention has lately been paid to the significance of phonotactics in language contacts (cf. e.g. J. Koivulehto 1979, 1981, and A. Plöger 1982), which has most probably been essential in the Baltic Finnic diphthong innovations too.

It is symptomatic that there are several front vowel forms in the scanty number of words with diphthongs of FU origin, while they are proportionally extremely uncommon among the loan words. The diphthong innovation adapted to the characteristic native vowel harmony in words like päivä, täi, löyly, 
köysi, etc., because Baltic influence was only indirect and could not affect such a dominant structural feature in the indigenous component of the lexicon. The situation was different as far as the loan words were concerned: Baltic Finnic adopted words in which vowel harmony had no relevance mainly with back-vowel shapes (some Baltic loans, however, have assumed a front-vowel shape, probably due to a later adaption to Baltic Finnic vowel harmony: $\mathrm{Fi}$ ankerias änkeriäs, Est. angerias; cf. Lith. ungurys, OPr angurgis).

The equivalents of Baltic *ai and *ei in Baltic Finnic reflect the ambiguous history of these diphthongs. Baltic *ei has been rendered in Baltic Finnic either by ei or by al: Fi. heinä, EstN hein, EstS hain (- Baltic *šeina), Fi. seinä, EstN sein, EstS sain (- Baltic *seina ?*saina) (J. Kalima 1936: 72-74). On the other hand, only ai occurs in some Baltic loan words in Baltic Finnic, which undoubtedly reflect either Baltic *ei or *ai: Fi. taivas, Est. taevas, Fi. kaima, Est. kaim, Fi. paimen, Est. paimendama. The puzzle becomes greater, because Lapp invariably shows only ai in all such loans. In modern Baltic both $a i$ and ei have often given ie: Lith. diẽvas < *deivas, liesas < *laisas. C. Stang 1966: 57 thinks that the diphthongs were close enough to merge into ${ }^{*} \bar{e}$ and end up as ie. The ambiguity in the Baltic Finnic substitution must reflect confusion in phonetic interpretation during language contacts. It is probable that for the Baltic Finnic speakers the difference between Baltic ai and ei was not clear and this caused "wrong" substitutions and dialectal variants (cf. EstN sein, EstS sain). This duality may also have a causal connection with the phonetic vacillation in native Finnic words like seisoa saizma, and it repeats itself in the substitution of Germanic loan words in Baltic Finnic. As a matter of fact, one of the crucial phonetic problems of these contacts is the question why e.g. Gmc *hlaibahas been rendered by Baltic Finnic leipä (Est. leib) and Gmc *gaizaz by Baltic Finnic keihäs (Veps keih, keijaz), while ai was normally retained in Baltic Finnic, as in Fi. paita (+ Gmc; cf. Goth. paida), Fi. laina, Est. laen (Gmc *laihna[z]). K. Liukkonen 1973: 21 tries to explain this dual outcome on the basis of native phonotactics. He points out that the vowel sequence $e-a$ ( $e$ in the first and $a$ in the second syllable) as well as diphthongs ending in $i$ were unknown in Pre-Baltic Finnic and supposes that all Baltic words of the type ei-a or ai-a were rendered in Baltic Finnic by *aj-a: *క̌ajna, *క̌ajma, 
*sajna, *sajßas *tajßas. This explanation implies a Proto-Baltic Finnic sound change ai $>e i$, associated with the generalization of the $e-a$ combinations in such words. However, there are no concrete arguments to assume a significant difference in time between the adoption of Baltic *ei *ai and the rise of the shape e-a. If this were true then the Baltic loan words kelta, kerta, nepaa, terva would clearly be later than those with ai and $e i$ in the first syllable. Rather, the Baltic ei-words could have supported the introduction of the new word type e-a. Thus the most natural explanation for the dual reflexes of Baltic *ei or *a $i$ in Baltic Finnic seems to be the ambiguity of phonetic interpretation in the bilingual context. Also the fact that the $a i$ $\sim e i$ variation occurs in native words and Germanic loans of different ages (Fi. seisoa, EstS saizma, Fi. seikka saikka, seipi saipi; leipä, keihäs, paita [ - Gmc *ail, peitto paitto, vaippa veipata) supports the idea that this duality reflects an old variation matched to a degree also in native material rather than a strict "real" completed sound change.

Baltic *au has been regularly rendered by au in loan words like Fi. kauha (cf. Lith. káušas) and laukki (cf. Lith. laũkis). Interesting exceptions are Fi. karva, Est. karv (cf. Lith. gaüras), Fi. tarvas, ? Est. tauras (cf. Lith. taüras) and Fi. torvi, Est. torv (cf. Lith. taurẽ). J. Kalima 1936: 75 contents himself with just noting this irregular substitution aur $>$ arv. But metathesis (a frequent change) could easily favor the sequence $r V$ as it is shared by both linguistic structures: cf. Lith. kárvé, kirvis, Baltic Finnic korva. ${ }^{1}$

The Baltic Finnic diphthong eu is particularly interesting from the historical point of view, because its rise seems to be tied with the very context of Baltic contacts. This diphthong has been considerably less productive than the others in later native and loan words (eu-words in SKES make up about $3 \%$ of all diphthong words). Proto-Baltic Finnic adopted at least two Baltic loan words which may reflect the Pre-Baltic diphthong *eu, represented now by Lith. Iau 'au: Fi. leuka, Est. Ioug (cf. Lith. liaukà) and Fi. reuna, Veps reün (cf. Lith. briauna). When the original diphthong was *eu, the consonant before au is palatalized in some cases (Lith. liádia, Latv.

I In this case there seems to be a native model for metathesis: Baltic Finnic korva derives from *kovra < Uralic *kåwi (J. Janhunen 1981: 253). Metathetic substitution seems to be regular also in Germanic loan words when the original contains the combination aur (J. Koivulehto 1979: 278-79). 
laudis), in other cases not (Lith. tauta, Old Pr. tauto). This indicates that the fusion of IE *au and *eu was/is not complete in Baltic. It is also possible, even if questionable, that the IE, Pre-Baltic diphthong *eu was still retained in the period of Baltic and Finnic contacts, and perhaps still later in Old Prussian, cf. Lit. kiáutas, Old Pr. keuto (C. Stang 1966: 73-74, W. Schmalstieg 1974: 19-20). Thus it seems that these Baltic loan words and the bilingual Baltic - Finnic interaction introduced the diphthong eu into Baltic Finnic. This diphthong need not necessarily directly reflect the Pre-Baltic *eu, as it can be interpreted equally well as rendering an intermediate palatal pronunciation between eu and au (like in Lith. lau = 'au). It does not occur in words older than Proto-Baltic Finnic (except in peukalo, an irregular derivation from Finnic-Permic *pelkä). Neither can it be explained on the basis of any indigeneous sound change. Thus a Baltic model for it becomes attractive.

The phonetic quality of e may have favoured the predominance of the front vowel variant eü, extant in modern Finnic only in Votian, Vepsian and Karelian examples. This variant is more frequent than eu both in native (FU and later) words and in Germanic loans, but through a secondary labialization eü> öu : Fi. höyhen, Est. ehme, ohme, Veps höüneh, heunez < *heühen (heuhen) < *ร̌euక̌em <*క̌evక̌em < *ร̌enక̌em, Fi. löyly, Est. leil, Votic leülü< *leülü, Fi. köyhä, Est. kehv < *keühä (- Gmc *skeuha-), Fi. pöytä, Est. põid $<$ *peütä (- Gmc *beuđa-). Under the influence of the back vowels in the following syllables eu may have been preserved in peukalo, as well as in neuvo (Est. nסu), leuto, and seutu which descend from Proto-Baltic Finnic at the earliest, while eü was introduced in to höyhen and löyly the whole structure of which is front-vocalic. Estonian has clearly tended to replace eu eü by a diphthong ending in i: peutä > póid, peukalo > peial. Votian, on the other hand, adds to its lexical token frequency of eu through the combinative change ou $>$ eu, bound to the general change $o>e$ (L. Kettunen 1930: $128,135)$.

New momentum for eu in Finnish has been provided by recent Russian loans, as in reuhka ( - Ru. treuh), seuna $(-$ Ru. Zegno), by descriptive words like peuhata, reuhtoa, and by the change et(r), ep(r), ek(l)>eu, in words like petra > peura, sepra > seura, nekla > neula (this, however, has been only partial, cf. Karel. sepra, Est. sőber, Karel. niekla, EstN noul, EstS negil, 
Karel. petra, Est põder, põdra). But the Baltic Finnic lexical occurences of eu have remained quite rare and limited, as is to be expected, since *eu in Proto-Baltic was subject to a change into (i)au, and would thus have had marginal significance in the Baltic - Finnic substitutional interaction.

Native Baltic Finnic words in ai, ei, au, and eu add up to about 100, i.e. 50 \% less than loan words which have these diphthongs in the first syllable. Most of them are either descriptive words like paiskata, raikua, heilua, leimu, laulaa, naukua, peuhata, or phonetically recent formations like Fi. vaihe, Est. vahe < *vaješ, kaiho, Est. kahi, Fi./Est. au-k- < ava-, nauris, Est. nairis < nakris, eilen, Est. eile < eklen, peura < petra.

Many arguments support the supposition that foreign influence played a decisive role in the Proto-Baltic Finnic diphthong innovation. First, one half of all Baltic Finnic diphthong words and two thirds of the $a i, e i, a u$, and eu words are loans. More than half of these, it is true, are recent Swedish or Russian borrowings into Finnish, but this amount corresponds to the general numerical proportion between old and new loans. The old Baltic and (later?) Germanic loan words and the language contacts reflected in them are crucial for the diphthong innovations. They contributed to the rise of the diphthongs ai, ei, au, and eu and eased them into the phonotactics of the native words.

Another indication of foreign influence comes from the striking amount of descriptive native words descending from Proto-Baltic Finnic or later stages. It is well known that foreign speech sounds are easily adopted in this category, as e.g. voiced stops in Karelian from Russian and initial consonant clusters in South-Western Finnish from Swedish offer proof of this (E. Itkonen 1966: 133, P. Ravila 1952: 270; for phonotactic innovations, cf. J. Koivulehto 1979 and 1979).

It is also worth noticing that most of the oldest Proto-Baltic Finnic diphthong words - prevalently loans - are back vocalic. Front vowel forms are mostly descriptive like Fi. häilyä, häipyä, häyry hauru, räyhätä, which as a rule belong to the younger lexical stratum, or are quite recent loans like Fi. päilyä ( - Swed. spegla), päistär ( - Ru. pasder). The absolute number of front vowel forms in Baltic Finnic falls short of that of the back vowels, but the difference is even more striking in the words with diphthongs. This may indicate that the diphthong innovation did not immediately adapt to 
vowel harmony, because of the high level of bilingualism among the Baltic speakers, but only later when the diphthongs were better acclimatized to Baltic Finnic phonotactics. Now front vowel forms would gain momentum. This process of adaptation may be reflected in some loans which originally entered with a back vowel and now display a front one, such as Fi. ankerias - änkeriäs, rastas - rästäs. In some cases the front vowel shape has even become exclusive: Fi. ätelä, Est. hädäl (- Baltic; cf. Lith. átolas), Fi. äiti, Est. eit ( - Gmc *aipi-). The same kind of back vowel predominance (48:10) has been observed by A. Plöger 1982 in the Baltic Finnic word structure $c \bar{V} C(C) a / a$, whose rise the author considers to be due to strong influence by foreign phonotactic models (p. 95).

II. oi, ou, ui, iu, üi

The rest of the 600 diphthong words, about 250 number, contain oi, ou, and $u i$, and in a few recent cases $i u$ and $\ddot{u} i$ in the first syllable. These Proto-Baltic Finnic diphthongs have no direct equivalent in Baltic or Germanic. Therefore it is probably no mere chance that words with one of these diphthongs in the first syllable contain fewer loans than the group treated above (ai, ei, au, and eu). Most of them, about $70 \%$, are descriptive or onomatopoeic like Fi. hoilata, roihu, houkuttaa haukuttaa (Est. augutada), huikata, liukas liukua luikua, riuska, riuhtoa, or words in which the diphthong is the result of a recent sound change as in Fi. kiuru< kirv-, koukku kokka, koura < kopra, puida < puu, suitset<suu, loima < lotma, toinen < tō + -inen, piusta < pidusta. About $25 \%$ are relatively recent Swedish or Russian loans, such as Fi. koisa (- Swed. kvesa), housut (Est. huus, aus) ( - Swed. hosa), kousa ( - Swed. kåsa, dial. kous), koulu ( - Swed. skola), huitu ( - Swed. hvit), piuttu (- Swed. sp jut), lyijy (- Swed. bly).

The diphthong ou occurs also in the older Germanic (Scandinavian) loan word stratum and probably reflects the change $a u>$ ou of the lending source Fi. lounita ( - Scand.; cf. ON launa), lousata ( - Scand.; cf. ON lauss). In a couple of old Baltic loans ou seems to correspond to Baltic au: Fi. louhia (? Baltic; cf. Lith. láužti), Fi. rouhia, Est. róhuma ( - Baltic; cf. Lith. krausýti). It could also be a question of a later development and not of direct substitution, if we consider such doublets as Fi. laukko loukko, etc. 
Nevertheless, some phonetic correspondence between Baltic au and Baltic Finnic ou evidently existed, as the substitution is reversed in one of the few Baltic Finnic loans in Baltic: Lith. laúnagas, Latv. launags (cf. Fi. lounas, Liv. IēnaG). The correspondence between Baltic au and Baltic Finnic ou finds its most natural explanation in the same situation as the rendering of Baltic $a$ with both $a$ and $o$ in Baltic Finnic (kaula, hammas, etc. vs. morsian, lohi, etc.). Baltic lacked $o$ and its a could be interpreted both as $a$ or $o$ in Baltic Finnic according to the context. In the opposite case it is clear that Baltic Finnic o could be rendered only a as in laúnagas.

About $5 \%$ of the words with oi, ou, and $u i$ in the first syllable are older than Proto-Baltic Finnic. On the basis of the FU cognates all the oi cases seem to derive from Pre-Finnic *oj-: Fi. koi, koira, koivu, noita, oikea, oiva, poika, soida, toipua, voi. Now, oi does not allow any direct Baltic model, as there are no sure examples of a Baltic *oi in the first syllable ( $C$. Stang 1966: 70). The Baltic Finnic vocalization *j> i may naturally be explained on the basis of the syllable-final position of $j$ before a consonant, expect for koi and voi where ${ }^{*} j$ gives $i$ at the end of a monosyllabic form (it is indeed typical that a pause acts like a consonant in a context like this). External influence could, however, favour a more distinctly vocalic pronunciation in old FU sequences V + semivowel: *kojvu>koivu, *pojka > poika; cf. *vajmo> vaimo, *äjmä> äimä. Bilingual substitution processes may have also affected the formation of Baltic Finnic ou in such Pre-Finnic words as Fi. jousi ( $<*$ jon-) and favoured the vocalization of $v$ in *tovko > touko, lovna $>$ louna. During the early language contacts Proto-Baltic could still have retained its long diphthong *ou, or its later development *uou which in modern Baltic has given vo (C. Stang 1966: 77). It is perhaps not improbable that the Baltic diphthong model has some influence on the change of the infrequent FU sound combination *-uy- into *ou in the first syllable, e.g. Fi. soutaa, Est. sõuda < FU. Pre-Finnic *suy-ta-, juoda, Est. juua (joon) $<*$ jō-< *jou- <*juy - in which one intermediate shape seems to have been the long diphthong *ōu: *jou- $>$ *jou- (E. Itkonen 1949: 13-14). Fur thermore, the diphthong ou occurs in Baltic Finnic at least in one Baltic loan word: Fi. routa, Votic reuta (cf. Lith. grúodas).

SKES gives only 5 words of FU origin with the diphthong $u i$ in the first syllable. In Fi./Est. hui, Fi. kuiva, Est. kuiv', and Fi. uida, Est. uim the diph- 
thong obviously derives from Pre-Finnic *uj-, while it is less motivated in Fi. kuiru and kuitu, Est. kiud. There is also a Baltic parallel to the ProtoBaltic Finnic diphthong vi, even if it is not possible to show credible chronological interaction. In Baltic $u i$ is relatively late and has been particularly prevalent in expressive words like Lith. tuikti, lüisas, etc. (C. Stang 1966: 70-72). In addition it is interesting that ui is so frequent in Slavic loans, e.g. Lith. muilas ( - Ru. mylo) that A. Senn 1966: 86 thinks it a phonetic loan. This Baltic parallel supports the essential idea of this article: because the words with diphthongs of Proto-Baltic Finnic and later times are to a large extent words of a descriptive nature or loans of different ages, they received important impetus from foreign sources.

The fate of the Proto-Baltic Finnic diphthongs has not been equal in all branches. Finnish has been the most prolific one, introducing three additional new (rising) diphthongs through the changes $\bar{e}>i e, \bar{o}>$ uo and $\ddot{o}>$ uö (cf. Fi. tie Est. tee, Fi. suo Est. soo, Fi. yö Est. öö). Secondary monophthongization has occurred in Livonian: tōvaz < taivas, lōja < laiva, sōna < sauna, etc. (L. Posti 1942: 30-35). This is no surprise because Livonian has been in close contact with modern Baltic (Latvian) which also shows a late tendency towards monophthongization (J. Endzelins 1971: 43). In general, however, the modern Baltic Finnic diphthong systems are rich, and considered conservative.

The preceding investigation throws light on the conservative nature of one language (or linguistic group) with respect to another and puts them in relative order. The situation of Baltic and Baltic Finnic diphthongs is in fact in a certain sense "paradoxical": with the rise of its diphthongs the Baltic Finnic vocalism, generally considered quite conservative, has undergone a radical phonotactic innovation in vowels, supported and regulated by the Baltic diphthong model. On the other hand, this innovation has in its turn frozen in Baltic Finnic producing one of its conservative features, unveiled especially by the Germanic loans. The original Germanic and Scandinavian diphthongs, monophthongized long ago in the original sources, have been preserved in the Baltic Finnic forms, e.g. Fi. rauta, Est. raud (- Gmc

1 Actually J. Koivulehto 1983 has recently shown that this word is a Germanic loan in Baltic Finnic. 
* rauða-; cf. Swed. röd). Fi./Est. kaunis (- Gmc *skauniz; cf. Swed. skön) and Fi. laina, Est. laen (- Gmc *laihna(z); cf. OSwed. lān). This is the famous mammoth bones effect of Finnish structure.

This study has combined the attested data from borrowing with the strong circumstantial evidence from Pre-Baltic Finnic reconstructions and from the later areal dynamics in language, culture, and chronology. The result is an attractive convergence filter for the Baltic Finnic diphthongs matching that given by Posti for the consonant inventory. Interestingly enough the filters work in opposite ways, the consonants are reduced and the vowels increase (cf. the syntagmatic/paradigmatic balances produced in sound changes, e.g. in umlaut phenomena). This kind of cumulative force is typical of "proof" in historical study. Historically well understood parallels exist (cf. Senn), e.g. the sound systems for p-Celtic (Brythonic) in France (Breton) vs. England (Welsh) have adapted to those of the dominant languages producing distinctly different qualities. For that matter, Finnish and Karelian, sharing most of the Baltic diphthongal reflexes here, do diverge in that the latter (together with its congeners) has later acquired a clear Russian flavor in its phonology.

EEVA UOTILA

\section{REFERENCES}

B. Collinder: Survey of the Uralic Languages. Uppsala 1957.

G. Décsy: Einführung in die finnisch-ugrische Sprachwissenschaft. Wiesbaden 1965.

J. Endzelins: Comparative Phonology and Morphology of the Baltic Languages. The Hague 1971.

L. Hakulinen: Suomen kielen rakenne ja kehitys. Keuruu 1979.

K. Häkkinen: Statistische Angaben zur Lautstruktur der finnischen Sprache. Finnisch-ugrische Mitteilungen 6/1982, 77-96.

E. Itkonen: Beiträge zur Geschichte der einsilbigen Wortstämme im Finnischen. Finnisch-Ugrische Forschungen 30/1949, 1-54. 
E. Itkonen: Suomen höyhen sanasta ja sen lappalaisesta vastineesta. Virittäjä $63 / 1959,306-312$.

E. Itkonen: Die Laut- und Formenstruktur der finnisch-ugrischen Grundsprache. Ural-Altaische Jahrbücher 34/1962, 187-210.

E. Itkonen: Kieli ja sen tutkimus. Helsinki 1966.

E. Itkonen: Wertung der fiugr. Lautforschung. Ural-altaische Jahrbücher $41 / 1969,76-111$.

J. Janhunen: Uralilaisen kantakielen sanastosta. SUSA 77: 9/1981, 219-274.

J. Kalima: Itämerensuomalaisten kielten balttilaiset lainasanat. Helsinki 1936.

L. Kettunen: Vatjan kielen äännehistoria. Helsinki 1930.

V. Kiparsky: Gibt es ein finnougrisches Substrat im Slavischen. Suomalaisen Tiedeakatemian Toimituksia B 153, 4/1969.

A. Klimas: Some Attempts to inventory Lithuanian Phonemes. Baltic Linguistics. University Park 1970, 93-108.

J. Koivulehto: Phonotaktik als Wegweiser in der Lehnwortforschung: die osfi. -str-Wörter. Finnisch-Ugrische Forschungen 43/1979, 67-79.

J. Koivulehto: Lainoja ja lainakerrostumia. Virittäjä 83/1979, 267-301.

J. Koivulehto: Paikan ja joukon tulo kieleen. Virittäjä 85/1981, 195-213.

J. Koivulehto: Zur Etymologie von finnisch kuiva und deutsch trocken. Neuphilogische Mitteilungen 84:1, 1983.

A. Kurschat: Litauisch-deutsches Wörterbuch. Göttingen 1973.

K. Liukkonen: Lisiä balttilais-suomalaisten lainasuhteiden tutkimukseen. Virittäjä 77/1973, 17-32.

L VF = Lapinmurteiden fonologiaa (E. Itkonen, T. Itkonen, M. Korhonen, P. Sammallahti). Castrenianumin toimitteita 1, Helsinki 1971.

A. Plöger: Uber die Entstehung des finnischen Stammtyps $c \bar{v} c(C) a / a ̈$. Finnisch-Ugrische Forschungen 44/1982, 66-98.

L. Posti: Grundzüge der livischen Lautgeschichte. Helsinki 1942.

L. Posti: From Pre-Finnic to Late Proto-Finnic. Finnisch-Ugrische Forschungen 31/1953, 1-91.

M. Rapola: Suomen kielen äännehistorian luennot. Helsinki 1966. 
P. Ravila: Onomatopoieettisten ja deskriptiivisten sanojen asema kielen äännesys teemissä. Virittäjä 56/1952, 262-274.

W. Schmalstieg: An Old Prussian Grammar. University Park 1974.

A. Senn: Handbuch der litauischen Sprache. Heidelberg 1966.

SKES = Suomen kielen etymologinen sanakir ja I-VI. Helsinki 1955-1978.

C. Stang: Vergleichende Grammatik der baltischen Sprachen. Oslo-BergenTromsö 1966.

W. Steinitz: Geschichte des finnisch-ugrischen Vokalismus. Berlin 1964.

O. Szemerényi: Einführung in die vergleichende Sprachwissenschaft. Darmstadt 1970.

W. Thomsen: Beröringer mellem de finske og de baltiske Sprog. Copenhagen 1890.

W. Veenker: Die Frage der finnougrischen Substrats in der russischen Sprache. Bloomington 1967.

Virittäjä 1953 = E. Itkonen, O. Ikola, A. Penttilä, J. Mägiste: Posti Lauri, From Pre-Finnic to Late Proto-Finnic, 306-311. 